\title{
COVID-19 IN INDONESIA: \\ ANALYSIS OF DIFFERENCES EARNINGS MANAGEMENT IN THE FIRST QUARTER
}

\author{
Widyaningsih Azizah* \\ Fakultas Ekonomi dan Bisnis, Universitas Pancasila, Indonesia \\ widyaningsih_azizah@univpancasila.ac.id
}

\begin{abstract}
The COVID-19 pandemic, which began in the first quarter (Q1) of 2020 in Indonesia, has certainly had a major impact on the company's financial performance. The first-quarter financial report should have been able to show the actual condition of the financial company because it can be a projection for investors and analysts regarding the company's performance in the next period. Unfortunately, many gaps in financial reporting that can provide space for management to commit earnings management. This study aims to prove the difference in earnings management in the Q1 of 2020, namely the period after the COVID-19 pandemic with the Q1 of 2019, namely the period before the COVID-19 pandemic. The data type of the research is secondary data using the financial statements of companies listed on the Indonesian Stock exchange in the Q1 of 2018, the Q1 of 2019, and the Q1 of 2020. The Q1 of 2018 is needed in this research related to the search for the Q1 of the year of 2019 data. Hypothesis testing was conducted using the Wilcoxon test with SPSS 25 software. This research has proven that there is a difference in earnings management in the Q1 of 2019, namely before the COVID-19 pandemic, and the Q1 of 2020, named after the COVID-19 pandemic. The level of earnings management during the COVID-19 pandemic represented in the Q1 of 2020 was lower than the earnings management in the period before the COVID-19 pandemic, namely in the Q1 of 2019.
\end{abstract}

Keywords: COVID-19 Pandemic, Earnings Management, Q1 of 2020, Q1 of 2019, Modified Jones Model, Wilcoxon Test.

*Corresponding author

Email: widyaningsih_azizah@univpancasila.ac.id

DOI: https://doi.org/10.33369/j.akuntansi.11.1.23-32

\section{INTRODUCTION}

In the first quarter (Q1) of 2020, the world was rocked by the COVID-19 pandemic, which forced various countries to reduce their economic activities. As a result, the economic growth of all countries is depressed. In some countries, the growth experienced depression, and some others continued to grow positively, although far below-normal growth. Bappenas RI (2020) describes the depressing economy from China which was depressed by $6.8 \%$. Japan was depressed deeper by $3.4 \%$. Meanwhile, the United States still grew positively by $0.3 \%$. Indonesia's economic growth was depressed by $2.97 \%$.

The spread of the 2019 Coronavirus Disease (COVID-19) started in the fish market in Wuhan, China, which occurred at the end of December 2019. The first cases of COVID19 in Indonesia began on March 2, 2020. The virus spreading was so quickly. In March 2020, more than 170 countries had reported cases of Covid-19 (Mukaromah, 2020). WHO, Bruce, Liang (2020) declared the coronavirus as a pandemic on March 11, 2020, and announced the name of this outbreak as Coronavirus Disease (COVID-19) caused by the Severe Acute Respiratory Syndrome Coronavirus-2 (SARS-CoV-2) virus.

WHO, Bruce, Liang (2020) explain that before the outbreak of COVID-19, 6 types of coronavirus could infect humans, namely alphacoronavirus 229E, alphacoronavirus NL63, betacoronavirus OC43, betacoronavirus HKU1, Severe Acute Respiratory Illness Coronavirus (SARS-CoV), and the Middle East Respiratory Syndrome Coronavirus (MERS-CoV). The SARS-CoV-2 sequence has similarities with the coronavirus isolated in bats, so the hypothesis is that SARS-CoV-2 originated from bats that then mutated and infected humans. Mammals and birds are thought to be intermediate reservoirs. Currently, 
the human-to-human spread of SARS-CoV-2 is the main source of transmission, so its spread has become more aggressive. SARS-CoV-2 transmission from symptomatic patients occurs through droplets that come out when coughing or sneezing.

Furthermore, in many cases, this virus only causes mild respiratory infections, such as flu. However, this virus can also cause severe respiratory infections, such as lung infections (pneumonia). World Health Organization (2020) These symptoms of COVID19 generally appear within 2 days to 2 weeks after the patient is exposed to the Coronavirus. The initial symptoms of COVID-19 can resemble flu symptoms, namely fever, runny nose, dry cough, sore throat, and headache. After that, the symptoms may disappear and the patient is healed, or even get worse. Patients with severe symptoms can experience high fever, cough with phlegm and even bleeding, shortness of breath, and chest pain. The action that must be taken if you feel symptoms of COVID-19 is to carry out independent isolation and then contact local health workers. COVID-19 is a newly discovered disease, therefore knowledge regarding prevention is still limited. The key to prevention includes breaking the chain of transmission with isolation, early detection, and basic protection (World Health Organization, 2020)

The rapid spread of the COVID-19 and can cause a risk of death if infected, causing people to limit their activities, as well as companies. Data from BPS (2020) proves that Indonesia's economic growth in the Q1 of 2020 to the Q4 of 2019 contracted by $2.41 \%$. This construction occurred in many field and expenditure components. Household expenditure consumption in the Q4 of 2019 was $2.71 \%$ but in the Q1 of 2020 only $1.56 \%$. Positive growth of the business field in the Q1 of 2020 occurred in sector agriculture, insurance, financial, forestry, fishery, information and communication, health services, and real estate.

The Minister of Finance of the Republic of Indonesia, Sri Mulyani said the decline of Indonesia's economic growth in the Q1 of 2020 was caused by the implementation of work from home and physical distancing during the COVID-19 pandemic in several counties. This policy was taken to reduce the spread of this virus. So, the activities outside the home were drastically reduced (Rahayu, 2020). Hidayat Amir, Head of Macroeconomic Fiscal Policy of the Ministry of Finance said the economic losses due to the spread of COVID-19 could be seen from Indonesia's economic growth in the Q1 of 2020 which declined considerably (Kencana, 2020). Figure 1 shows Indonesia's Economic Growth:

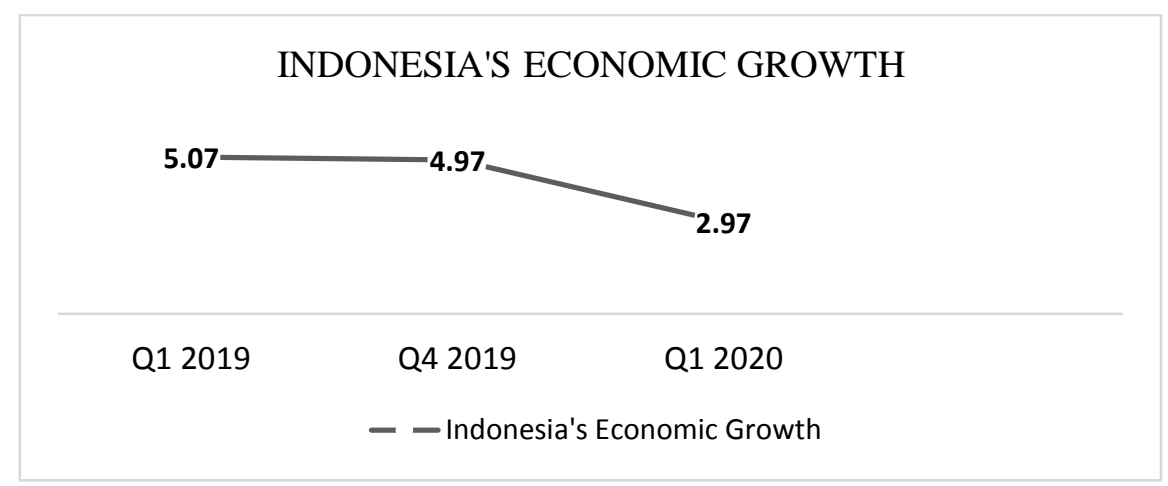

Figure 1. Indonesia's Economic Growth

Source: BPS (2020)

Indonesia's Economic growth in the Q1 of 2019 was $5.07 \%$, Q4 of 2019 was $4.97 \%$, and Q1 of 2020 was $2.97 \%$. In the Q1 of 2020, Indonesia's economic growth could still grow by $2,97 \%$. But, it's lower than Q4 of 2019. And much lower than the realization of economic growth in Q1 of 2019. 
To prevent its wider spread, several countries have implemented lockdown policies. China implemented the first lockdown from $23^{\text {rd }}$, January 2020 to $8^{\text {th }}$ April 2020. In Indonesia, lockdowns are known as Large-Scale Social Restrictions (PSBB). The implementation of lockdown policies pursued by several major countries in the world has caused social restrictions in the form of movement of people and also a movement of goods so that it plays a role in hampering the global demand, production, and distribution in the business world. The global health crisis that occurred in the Q1 of 2020 had an impact on the performance of the domestic economy. In the Q1 of 2020, almost all sectors in Indonesia grew slow down. This was due to the decrease in global and domestic demand and commodity prices (Bappenas RI, 2020).

China and United States are Indonesia's trading partners. China is the main destination for export (about 15\%). Lockdown and restricted public activities in China had an impact on Indonesia's export were hampered. Import of raw materials from China had also decreased, this was due to the cessation of business activities in China due to the COVID-19. The impact of the disruption in the supply of raw materials and capital goods from China affected domestic production activities in the Q1 of 2020. The impact of COVID-19 had hit the export and import sectors, then the chain effect would affect the household consumption, household consumption was starting to be limited and to the investment sectors.

The recession in the United States has decreased consumer purchasing power, and automatically export demand such as commodities, textiles, apparel, wood products, and footwear would decline. The US economic recession had a significant impact on Indonesian trade. The United States is Indonesia's largest trading partner after China, about $10 \% .50 \%$ of Indonesia's footwear and textile exports sent to the United States. Meanwhile, textile and textile products are one of Indonesia's leading export products. This means that the United States recession has the potential to further suppress Indonesia's export performance this year.

The decline in company revenue as a result of the COVID-19 pandemic has resulted in companies taking efficiency measures. Many companies in the manufacturing sector are cutting production in anticipation, even temporarily halting production activities. As reported by Damaran and Harjanto (2020), one of those affected is PT. Toyota Motor Manufacturing Indonesia, which has 5 factories in Sunter Jakarta and Karawang with 7,863 employees, has reduced 50\% of production activities since a few weeks ago in March 2020 and plans to close the factories. Hanoatubun (2016) explains that the presence of the coronavirus has affected market projections, investors will delay their investment due to unclear supply chains or due to changing market assumptions.

A contractual relationship between the company owner (principal) and the manager (agent) in which the owner gives responsibility to the manager to manage the company on behalf of the owner. The owner expects the value of his company to increase so that the owner's welfare will increase. This will encourage the owner to provide various incentives to encourage the manager to continue working hard. Managers in various ways try to meet the demands of the owner.

Financial reports, which have been the spearhead of companies in reporting their performance, continue to be demanded so that they can show good performance during the COVID-19 pandemic. Unfortunately, due to the asymmetry of information owned by the manager, it encourages the manager to report good financial performance even though the situation faced by the company is in difficult conditions (Azizah, 2017a). Researches by (Majid et al., 2020), (Romantis et al., 2020), (Azizah, Bantasyam, et al., 2020), (Azizah et al., 2019), (Azizah, Zoebaedi, et al., 2020) prove that managers in Indonesia carry out 
earnings management. Managers consciously carry out earnings management for their interests.

In the agency relationship, problems will arise if there is information that is unequally distributed between the agent and the principal which is called information asymmetry. The result of the information asymmetry is that the owner cannot oversee all the efforts made by the agent. This causes agents to have dysfunctional behavior. One example of dysfunctional behaviors done by agents is manipulating accounting numbers in financial reports (Sihombing \& Rahardjo, 2019). Managers are driven to maximize their interests by beautifying the financial statements so that they are in line with the owner's expectations, even though the financial statements do not describe the actual condition of the company.

(Azizah, 2017b) proves that the perspective underlying the practice of earnings management is opportunistic. Managers consciously carry out earning management to display financial reports that look good for their interests. This research is different from previous research because it takes the Covid-19 pandemic period as the research period and compares it to the period before the Covid-19 pandemic. For example Asni \& Mayasari (2018) differences in earnings management before and after IFRS adoption. Some research in Indonesia discusses the effects of the Covid-19 pandemic on earnings management.

During the COVID-19 pandemic, through the first-quarter financial reports, managers have to show the performance of the companies they lead. The Q1 financial report can be used by investors or other users of financial statements in predicting the companies' performance in the next period. The instability of the financial condition currently faced by the company causes management to tend to experience pressure, where it can have an impact on management's actions to commit earnings management. Because managers eager to be assessed well for their performance. Thus, companies must be able to show sustainable performance to attract investors and not to lose their existing investors.

Based on this explanation, the researcher is interested in conducting a study entitled "COVID 19 in Indonesia: Analysis of Differences Earnings Management in the First Quarter". This study aims to prove the difference between earnings management in the Q1 of the COVID-19 period and the Q1 of 2019 before COVID-19. This research is useful for investors and users of financial reports to be more careful in analyzing financial reports.

\section{RESEARCH METHODS}

The population of this research is all manufacturing companies listed on the Indonesia Stock Exchange. This study uses the Q1 of 2020 as the period after the COVID-19 pandemic and the Q1 of 2019 for the period before the COVID-19 pandemic. This research uses the purposive sampling method. The criteria used in sampling are as follows:

1. The companies are listed on the Indonesia Stock Exchange. They are classified in the manufacturing industry.

2. The companies publish financial statements for the Q1 of 2018, the Q1 of 2019, and the Q1 of 2020.

3. Research data is presented in published financial reports.

The first case of COVID-19 occurred at the end of December 2019 in China and spread widely to various countries in the world in a very short period. In the early year 2020, the spread of COVID-19 occurred widely. The spread of COVID-19 is very fast and until now no medicine for it has made the public preventive. The lockdown in China began at the end of January 2020 and there was widespread news about the fatal effects of infected Covid-19 which cause death. The Indonesian economy, which grew below the average in the Q1 of 2020 showed the Indonesian economy was affected by the Covid-19 pandemic (Kencana, 2020). The 
period before the COVID-19 pandemic and the period during the COVID-19 pandemic will be the differentiating variables in this study. The period before the COVID-19 pandemic (pre-test) is the Q1 of 2019 and the period after the COVID-19 pandemic (post-test) is the Q1 of 2020.

Agency theory describes the relationship between shareholders as the principal and management as the agent in a cooperation contract called the nexus of contract. However, there are often differences in interests between management and shareholders. This difference in interest causes a conflict of interest between two parties. Earnings management can occur when management has certain interests compile an income statement that is following its purpose and ruled out principal interests. Earnings management practices can be carried out in several ways, including the selection of accounting methods and accrual policies. According to Sihombing \& Rahardjo (2019), discretionary accruals can be used as a proxy for earning management. Therefore, the proxy for earnings management in this study uses the discretionary accrual value of the modified Jones model.

$$
\begin{aligned}
& T A C C_{i t}=E B X I_{i t}-C F O_{i t} \ldots \ldots \ldots \ldots \text { (1) } \\
& \frac{T A C C_{i t}}{T A_{i, t-1}}=\alpha_{1}\left(\frac{1}{T A_{i, t-1}}\right)+\alpha_{2}\left(\frac{\Delta R E V_{i t}}{T A_{i, t-1}}\right)+\alpha_{3}\left(\frac{P P E_{i t}}{T A_{i, t-1}}\right)+e
\end{aligned}
$$

The coefficient estimates from equation (2) are used to estimate the non-discretionary accruals (NDACC) for our sample firms:

$$
N D A C C_{i t}=\alpha_{1}\left(\frac{1}{T A_{i, t-1}}\right)+\alpha_{2}\left(\frac{\Delta R E V_{i t}-\Delta R E C_{i t}}{T A_{i, t-1}}\right)+\alpha_{3}\left(\frac{P P E_{i t}}{T A_{i, t-1}}\right) \ldots \ldots \ldots \ldots
$$

Furthermore, discretionary accrual (DACC) can be calculated as follows:

$$
D A C C_{i t}=\left(\frac{T A C C_{i t}}{T A_{i, t-1}}\right)-N D A C C_{i t} \ldots \ldots \ldots \ldots
$$

Notes:

EBXI $=$ Earnings before extraordinary items and discontinued operations

$\mathrm{CFO}=$ Operating cash flows (from continuing operations) taken from the statement

$\mathrm{TA}=$ Total assets

$\mathrm{REV}=$ Revenues

$\mathrm{REC}=$ Accounts receivable

PPE $=$ Gross value of property, plant, and equipment

The modified Jones model is a development of the Jones model which can detect earnings management better than other models such as the Healy, DeAngelo, Jones, and industry models. Besides, Islam et al. (2011) prove that the modified jones model is an effective model for detecting earnings management in developed and developing countries.

To test the differences in earnings management in the period before the COVID-19 pandemic and after the COVID-19 pandemic, the Paired sample T-test was used if the residuals were normally distributed. The normality test used the Kolmogorov Smirnov test using a significance level of 0.05 . However, if it does not pass the normality test, then to test the differences in earnings management in the period before the COVID-19 pandemic and after the COVID-19 pandemic, the Wilcoxon Test. The level of significance $(\alpha)$ is $5 \%$.

\section{RESULTS AND DISCUSSION}

Based on the sample selection criteria in table 1, there are 62 companies were selected as samples in this study. 
Table 1. Sample Selection Criteria

\begin{tabular}{lc}
\hline \multicolumn{1}{c}{ Description } & $\begin{array}{c}\text { Number of } \\
\text { Companies }\end{array}$ \\
\hline Companies registered consecutively in Q1 2018, Q1 2019, Q1 2020 & 80 \\
\hline Incomplete data & $(18)$ \\
\hline Sample companies & 62 \\
\hline
\end{tabular}

Based on normality testing using the Kolmogorov Smirnov test, the significance value of earnings management in the period before the COVID-19 pandemic was 0,000, and after the COVID-19 pandemic was 0.05 indicating that the residuals were not normally distributed. Then the Wilcoxon test was used to test the hypothesis.

The results of hypothesis testing using the Wilcoxon test show that Asymp.Sig. (2 tailed) is worth $0.000<0.05$. It can be concluded that $\mathrm{Ha}$ is accepted, meaning that there is a difference in earnings management for the pretest (before the COVID-19 pandemic) and the posttest (after the COVID-19 pandemic). Therefore, it can be concluded that there was an influence from the COVID-19 pandemic on earnings management in manufacturing companies in Indonesia during the Q1.

As can be seen in table 2, this difference can be proven by the average value of earnings management in the Q1 of the period after the COVID-19 pandemic shows a relatively smaller number (even on average it shows no earnings management at all) than the average value of earnings management for the Q1 of the period before the COVID-19 pandemic. The minimum and maximum value of earnings management in the Q1 before the COVID-19 pandemic were higher than the Q1 after the COVID-19 pandemic.

Table 2. The Comparison of Earnings Management

\begin{tabular}{lcc}
\hline \multicolumn{1}{c}{ Description } & Q1 of 2019 & Q1 of 2020 \\
\hline Average Value & -0.0000002 & 0.0000000 \\
\hline Minimum Value & -0.69439 & -0.15744 \\
\hline Maximum Value & 9.50324 & 0.17707 \\
\hline
\end{tabular}

The financial crisis as a result of the COVID-19 pandemic faced by the company did not cause the company to sporadically commit earnings management in the Q1 of 2020. The results of this study are not in line with the researches conducted by Gupta \& Suartana (2018), Gamayuni (2011) who state that earnings management behavior will increase along with the increasing level of company financial difficulties. The COVID-19 pandemic, which has occurred globally, has managers more careful in managing their companies. During the Q1 of 2020, companies continued to commit earnings management, but with much smaller numbers than the period before the COVID-19 pandemic.

As can be seen in table 3, the Average value of earnings management from each subsector in the sample companies were obtained by using the absolute discretionary accrual value. The highest average value of earnings management in Q1 2019 is the household equipment sub-sector, with an average value of 3.055, while the lowest average value is for the animal feed sub-sector, 0.10164. In Q1 of 2020, the highest average value is in the footwear sub-sector with a value of 0.0841 and the lowest average value is in the metals and the like sub-sector with a value of 0.00092 .

Table 3. Average Value Earnings Management of Each Sub-Sector

\begin{tabular}{lcc}
\hline Sub-Sector & Q1 2020 & Q1 2019 \\
\hline Cement & 0,013149 & 0,115708 \\
\hline
\end{tabular}




\begin{tabular}{lll}
\hline Porcelain and glass ceramics & 0,022967 & 0,150583 \\
\hline Metals and the like & 0,00092 & 0,253695 \\
\hline Chemicals & 0,021277 & 0,148632 \\
\hline Plastics and packaging & 0,010608 & 0,110644 \\
\hline Animal feed & 0,014537 & 0,10164 \\
\hline Wood and processing & 0,068601 & 0,12317 \\
\hline Pulp and paper & 0,028881 & 0,1456 \\
\hline Automotive and components & 0,010967 & 0,145453 \\
\hline Footwear & 0,084196 & 0,15605 \\
\hline Cables & 0,003178 & 0,150627 \\
\hline Food and beverages & 0,005251 & 0,168494 \\
\hline Cigarettes & 0,042027 & 0,20933 \\
\hline Pharmaceuticals & 0,020346 & 0,132007 \\
\hline Cosmetics and household goods & 0,001179 & 0,127483 \\
\hline Household appliances & 0,0118 & 3,055407 \\
\hline
\end{tabular}

The COVID-19 pandemic, which began in Q1, which resulted in a global financial crisis, seems to have made shareholders and investors understand this condition. Therefore, financial reports that show unfavorable performance are understandable. However, managers still beautify it by making lightly earnings management. If managers remain ambitious to show good company performance during the COVID-19 pandemic, even though they are not, it will raise suspicion from the public, analysts, auditors, investors, and even shareholders. This aggressive action by the manager can threaten his/her position.

\section{CONCLUSIONS AND SUGGESTION}

The COVID-19 pandemic has triggered the contraction of economic growth in the Q1 of 2020, not only in Indonesia but also in other countries (Bappenas RI, 2020). Starting from falling the prices of oil and gas, to quarantining activities such as a lockdown in several countries. The Covid-19 pandemic has an impact not only on the health crisis, but also on the economic crisis, and manufacturing companies are no exception. Managers as company administrators are required to show optimal performance.

This study aims to prove the difference in earnings management for the Q1 of 2020 (the period after the COVID-19 pandemic) and the Q1 of 2019 (before the COVID-19 pandemic). The results of this study prove that there are differences in earnings management for the Q1 of 2019 (before the COVID-19 pandemic) and the Q1 of 2020 (after the COVID-19 pandemic). It can be concluded that there is an influence from the COVID-19 pandemic on earnings management in manufacturing companies in Indonesia during the Q1.

The deteriorating economic conditions starting in the Q1 of 2020, as a result of the COVID-19 pandemic, did not cause companies to commit earnings management in the Q1 sporadically. This shows that managers are more careful in managing their companies, and do not want to stand out amid the COVID-19 pandemic. This happens if the manager cannot show the real performance of his company.

The limitations of this study are that this research used only manufacturing companies listed on the IDX, and focused only on the Q1 of financial statements as the initial impact of this pandemic. Not all manufacturing companies listed on the IDX during the study period were sampled due to limited data from the Q1 financial reports of several manufacturing companies 
available for research needs. The third limitation is that earnings management in this research is measured by the discretionary accrual value of the modified Jones model only.

For further research, it is suggested to expand the area of the research population, by using both manufacturing and non-manufacturing companies. Next, the research period related to earnings management can be expanded by comparing year to year. Third, further research can use other measurements to measure earnings management to provide alternatives and comparisons to improve the quality of future studies.

\section{REFERENCES}

Asni, F., \& Mayasari, M. (2018). Perbedaan Manajemen Laba Akrual Dan Manajemen Laba Rill Sebelum Dan Sesudah Adopsi Ifrs Pada Perusahaan Manufaktur Yang Terdaftar Di Bei. Journal of Applied Managerial Accounting, 2 (1), 82-87. https://doi.org/10.30871/jama.v2i1.721

Azizah, W. (2017a). Opportunistic Perspective off Accrual And Real Earnings Management in Indonesia. IOSR Journal of Business and Management, 19 (11), 1-05. https://doi.org/10.9790/487X-1911070105.

(2017b). Trend and Tradeoff Between Accrual Earnings Management and Real Earnings Management In Indonesia. Jurnal Media Riset Akuntansi, Auditing \& Informasi, 17(2), 159-172. https://doi.org/http://dx.doi.org/10.25105/mraai.v17i2.2079

, Bantasyam, S., \& Sinaga, L. (2020). Indonesia's LQ45 Index: Tax Discount Facility and Earnings Management. IOSR Journal of Business and Management (IOSRJBM), 22(8), 27-31. https://doi.org/10.9790/487X-2208032731

, Zoebadi, F., Bantasyam, S., \& Oktaviani, Y. R. (2019). Earnings Management in Indonesia: Are Women Always Under? IOSR Journal of Business and Management (IOSR-JBM), 21(11), 42-46. https://doi.org/10.9790/487X-2111014246

, Zoebaedi, F., \& Yatim, M. R. (2020). Income Smoothing: Does Firm Size Matter in Indonesia? IOSR Journal of Business and Management (IOSR-JBM), 22(11), 21-23. https://doi.org/10.9790/487X-2211042123

Bappenas RI. (2020). Perkembangan Ekonomi Indonesia dan Dunia untuk Triwulan I 2020. Bappenas RI, 4 (1), 1-89. https://www.bappenas.go.id/files/4215/9236/1094/ND_269_Penyampaian_Laporan_Per kembangan_Ekonomi_Indonesia_dan_Dunia_untuk_Triwulan_I_Tahun_2020.pdf.

BPS. (2020). Statistik Pertumbuhan Ekonomi Indonesia Triwulan I-2020. Www.Bps.Go.Id, 17, 2. https://www.bps.go.id/pressrelease/2020/05/05/1736/ekonomi-indonesia-triwulan-i2020-tumbuh-2-97-persen.html.

Damaran, Dionisio dan Setyo Aji Harjanto. 2020. (2020). Sentimen COVID-19: Pabrik Toyota Bersiap Shutdown. https://koran.bisnis.com/m/read/20200330/453/1219382/sentimencovid-19-pabrik-toyota-bersiap-shutdown. Accessed on April, 5th 2020.

Gamayuni, R. R. (2011). Ketepatan Model Altman Sebagai Prediktor Kebangkrutan. Jurnal 
Akuntansi Dan Keuangan, 16(2), 158-176.

Gupta, A. T., \& Suartana, I. W. (2018). Pengaruh Financial Distress dan Kualitas Corporate Governance Pada Manajemen Laba. E-Jurnal Akuntansi, 23, 1495-1520. https://doi.org/10.24843/EJA.2018.v23.i02.p26.

Hanoatubun, S. (2016). Dampak Covid-19 Terhadap Perekonomian Indonesia. E-Jurnal Manajemen Universitas Udayana, 5(11), 249101.

Islam, M. A., Ali, R., \& Ahmad, Z. (2011). Is Modified Jones Model Effective in Detecting Earnings Management? Evidence from A Developing Economy. International Journal of Economics and Finance, 3(2). https://doi.org/10.5539/ijef.v3n2p116.

Kencana, Maulandy Rizki Bayu. 2020. Pertumbuhan Ekonomi Kuartal I 2020 Jadi Gambaran Kerugian Akibat Corona. https://www.liputan6.com/bisnis/read/4269009/pertumbuhanekonomi-kuartal-i-2020-jadi-gambaran-kerugian-akibat-corona. Accessed December, 11th 2020.

Majid, M., Lysandra, S., Masri, I., \& Azizah, W. (2020). Pengaruh Kecakapan Manajerial Terhadap Manajemen Laba Akrual Dan Riil (Studi Empiris pada Perusahaan LQ45 yang Terdaftar di Bursa Efek Indonesia Periode 2016?2018). Jurnal Ilmiah Akuntansi Dan $\begin{array}{llll}\text { Manajemen } & \text { (JIAM), } & \text { (1), } & \text { 70-84. }\end{array}$ http://ejurnal.ubharajaya.ac.id/index.php/JIAM/article/view/115.

Mukaromah, Vina.Fadhrotul. 2020. Update Virus Corona di Dunia 30 Maret 2020: 720.117 Terinfeksi, $\quad 149.082$ Sembuh. https://www.kompas.com/tren/read/2020/03/30/071734165/update-virus-corona-didunia-30-maret-2020-720117-terinfeksi-149082-sembuh?page=all. Accessed on April, 5th 2020.

Rahayu, P. (2020). Siaran Pers : Pemerintah Waspada Dampak Pandemi Covid-19 Terhadap Ekonomi Indonesia. Kementrian Keuangan Republik Indonesia, SP-27/KLI/(April), 1721. https://www.kemenkeu.go.id/media/15072/sp-27-pemerintah-waspada-dampakpandemi-covid-19-terhadap-ekonomi-indonesia.pdf.

Romantis, O., Heriansyah, K., Soemarsono, D. W., \& Azizah, W. (2020). Pengaruh Perencanaan Pajak Terhadap Manajemen Laba yang Dimoderasi Oleh Penurunan Tarif Pajak (Diskon Pajak). Jurnal Ilmiah Akuntansi Dan Manajemen (JIAM), 16(1), 85-95. http://ejurnal.ubharajaya.ac.id/index.php/JIAM/article/view/116.

Sihombing, K. S., \& Rahardjo, S. N. (2019). Analisis Fraud Diamond Dalam Mendeteksi Financial Statement Fraud: Studi Empiris Pada Perusahaan Manufaktur Yang Terdaftar Di Bursa Efek Indonesia (Bei) Tahun 2016 - 2018. Prosiding Seminar Nasional Cendekiawan, 03, 2. https://doi.org/10.25105/semnas.v0i0.5780.

Who, \& Aylward, Bruce (WHO); Liang, W. (PRC). (2020). Report of the WHO-China Joint Mission on Coronavirus Disease 2019 (COVID-19). The WHO-China Joint Mission on Coronavirus Disease 2019, 2019(February), 16-24. https://www.who.int/docs/defaultsource/coronaviruse/who-china-joint-mission-on-covid-19-final-report.pdf. 
COVID-19 IN INDONESIA: ANALYSIS OF DIFFERENCES EARNINGS MANAGEMENT

IN THE FIRST QUARTER

Widyaningsih Azizah

World Health Organization. (2020). Laboratory biosafety guidance related to coronavirus disease (COVID-19). Interim Guidance, 19 March, 1-5. 